\title{
The church of Saint Anthony of Padua in Zagreb: later additions to heritage
}

\author{
N. Jaksic \\ School of Architecture, University of Zagreb, Croatia
}

\begin{abstract}
The church of Saint Anthony of Padua in Zagreb was built in 1934 and represents a valuable ecclesiastical monument of the Modern Movement. It was originally designed with a crypt and a tower that were not built at the time. The aim of this paper is to emphasize the importance of a correct reading and understanding of the complexity of architecture in order to provide a proper methodology for its (re)construction and site preservation. Eight thoroughly analysed and evaluated elements of the original architectural design programme, context, concept, form and space, movement, technology as well as perceptual and conceptual readings - provide more objective information of their value and help in assessing the achieved architectural quality of the church and its later additions. The church tower, which has now been recently built, has the same form and purpose as the original tower design, but other elements have contributed to disharmony with the church's design. It has become the primary focus of the site instead of the unambiguous expressiveness of the original design of the church complex. The comprehensive method used in this study proved to be a useful tool. It is possible to create appropriate later additions to built heritage, but the above eight elements have to be carefully evaluated before making decisions.
\end{abstract}

Keywords: addition, analytic method, church, reconstruction, $20^{\text {th }}$ century heritage.

\section{Background}

Even though $20^{\text {th }}$ century Modern Movement architecture in Croatia is recognized for its quality, recent actions encouraged by investors are quite alarming. There are cases varying from complete demolitions to unsuitable 
additions. Demolitions are mostly led by the economic value of the site and are not justified.

\subsection{Additions to built heritage in current conservation practices}

There is a certain haziness within current conservation practice regarding later additions. All actions that directly or indirectly change the attributes, shape, meaning and appearance of cultural property, and jeopardize its value, are prohibited by Croatia's Act on the Protection and Preservation of Cultural Goods [1].

Some charters and declarations of internationally recognized organizations responsible for cultural heritage provide some guidance on the matter. They suggest that new work, such as alterations or additions, is appropriate only if it does not distort, obscure or detract from the interesting parts of the building, its traditional setting and cultural significance, its interpretation and appreciation [2-4].

The manner in which such additions should be executed is also addressed generally. They should be compatible with the original fabric but sufficiently distinct from it. They should respect and enhance the spirit of the original and echo contemporary ideas $[3,5]$. The policy for managing a place must be based on an understanding of its cultural significance, and it should also include factors such as the owner's needs, resources and external constraints, and its physical condition for further development [4]. Comprehensive documentation should be studied thoroughly before any addition is carried out [8]. A correct evaluation of the heritage must be provided as well as its protection and conservation, and the promotion of its artistic and spiritual enjoyment [6]. Therefore, a multidisciplinary team should work together at all stages of the project [7].

It is also important to respect the existing integrity and to aim at the integrity of the old and new components to create a unique product [7] and overall quality solution. Special attention should be given to performance as well as to appearance [5]. It is important that additions to architecture are built to a high quality because today's new additions will be the heritage of tomorrow [8].

\subsection{The church of Saint Anthony of Padua and its late additions}

The church of Saint Anthony of Padua in Zagreb, a valuable ecclesiastical monument of the Modern Movement built in 1934, belongs to a group of heritage buildings that originally consisted of several elements. The original project for the complex, with a crypt and a tower, has never been completely realized (fig. 1). Even though the plans are preserved, the needs and context have changed. A church hall was built in 1970 on the crypt's planned location and the tower in 2008.

The author of the original project was architect Juraj Denzler (1896-1981, Zagreb). He was one of the most important Modern Movement architects in Croatia. His church designs clearly reflect the purpose of a church and stand out with their conceptual integrity, the innovative simplicity of composition created with traditional elements, as well as creating memorable conceptual pictures [9]. 


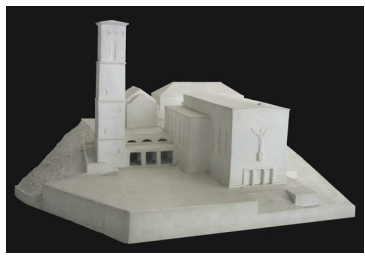

Figure 1: The original model of the church complex of Saint Anthony of Padua in Zagreb.

The bell tower construction still raises many questions in the community. Since the main attributes of the original design were not sufficiently considered prior the latest interventions, now the construction has been completed it only remains to assess the real quality achieved by the additions, by comprehensive analysis of this work of architecture.

\section{Aim and objectives}

The aim of this paper is to emphasize the importance of a correct reading and understanding of the complexity of architecture in order to provide a proper methodology for its (re)construction and therefore preservation.

The specific objectives of this paper are:

- to analyse attributes of the original church complex project,

- to analyse attributes of the later church additions: the church hall and tower,

- to compare the later additions with the original project and evaluate the resulting interaction.

\section{Analytic method}

The comprehensive analytical method used in this paper has already been proved to be helpful in providing the essential attributes of a work of architecture [10]. Here is the brief summary of the method. The eight basic attributes can be grouped in the four main groups A, B, C and D (fig. 2):

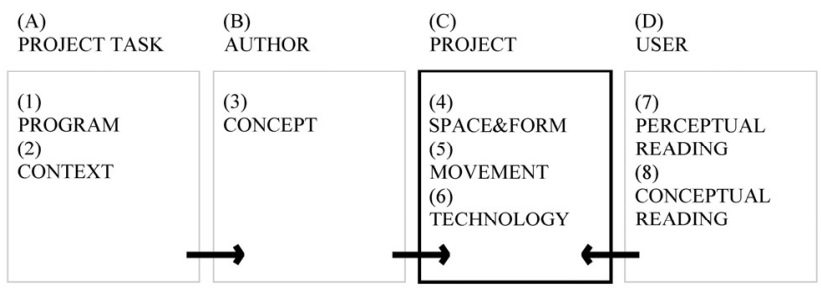

Figure 2: Analytic evaluation of architecture. 
(A) Project task represents certain conditions: (1) Programme and (2) Context. Every building is created as an answer to a programme, the wishes, needs and aims of an investor as well as social, economic and legal factors. The building is analysed in relation to its position and its surroundings.

(B) The author accepts a project task and creates (3) Concept. It is a basic, specific composition of attributes: a primary morphological composition and its perceptual readings and conceptual meanings.

(C) A project or realization ("silent witness") offers enough elements to analyse a building objectively and impartially. This group contains three analytic points: (4) Space and form, (5) Movement and (6) Technology. The space and functional organization and its form are worked out. In this paper, the building's approaches and entrance, path configurations, and relations between paths and space are also analysed. The main construction system, use of material and durability of these elements are taken into consideration.

(D) Usually, there is an impression made on a user or an observer by a work of architecture. There are two ways to read a building: (7) Perceptual reading and (8) Conceptual reading. The former analyses sensory perception and recognition of elements. The latter analyses images, patterns, signs and symbols created by the building or one of its elements.

The thoroughly analysed and evaluated attributes of the original architectural design provide more objective information of the design's value and will be used to assess the architectural quality achieved by the church's later additions. A comparison of the attributes will show possible similarities and differences of the attributes and assess the overall architectural contribution of the additions to the complex.

\section{Results}

\subsection{Programme}

A sanctuary and a votive church of Croats had to be built to mark the $700^{\text {th }}$ anniversary of the death of Saint Anthony of Padua and to meet the needs of the north-western part of Zagreb [11]. The existing complex of the chapel of the Holy Spirit, the Franciscan monastery and the building for Catholic community services (the House of Saint Francis) had to be enlarged with a new church, a church hall, and a parish priest's office. Of these, only the new church of Saint Anthony was realized at the time. The existing House of Saint Francis was adapted as a parish priest's office. After the Second World War, during communist rule, the House of Saint Francis was no longer the property of the Franciscans and the need for a church hall emerged. It was built in place of the crypt envisaged by the original plans. There has been significant investment in the monastery complex since the fall of communism. The new bell tower is 
intended for diverse activities and religious associations patronized by the Franciscans.

\subsection{Context}

The site is located on a hill and divided into two parts: the northern, higher part with the old monastery complex, and the southern part for the new church complex. The site is bounded by two narrow roads that meet at the site's southernmost point. The architect positioned the new complex as far north and as close to the centre of the site as possible (fig. 3a). The main church entrance and its wide staircase are on the main approach road axis from the south. A large triangular pavement was planned to emphasize the entrance. A square to the south, at the level of the entrance, was also planned to stand in front of the tower and the crypt. The addition of the tower is in its original position, while the church hall stands where the crypt was to be positioned (fig 3b). The main approach to the site does not have the same impressive, monumental character. Instead of the south square there is a car park. Trees shield the view towards the later additions. The car park's access road cuts across the pedestrian path. The tower and church can be seen from the surrounding area and Zagreb's main street, Ilica. Impressive views are to be had from the top of the tower.

\subsection{Concept}

The main design concept consists of the two dominant rectangular prismatic forms, the church and the tower that are connected by a third one, the crypt's portico (fig. 3a). The crypt is a part of the supporting system of the site's northern part. The later additions follow the design concept to some extent (fig. $3 \mathrm{~b})$. The portico has become a part of the church hall, thus direct communication between the tower and the church is not possible.

a

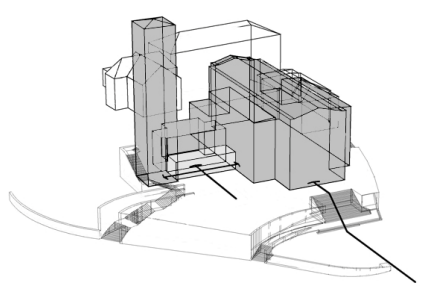

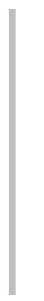

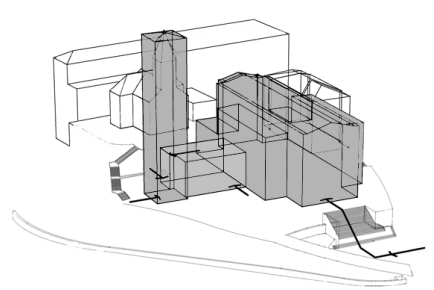

Figure 3: Context and concept attributes: a) the original project, b) the new additions.

\subsection{Space and form}

The original composition has a clustered spatial organization (fig. 4a). Its spaces are linked by a common space, a portico. The church consists of an entrancevestibule, a nave with side aisles and a chancel on the main axis. There is a sacristy on the east side, and a chapel on the west side of the chancel. The 
integrity of the inner space, simple geometric elements, reduced aesthetics, scale and emphasized spirituality, was considered a revolutionary idea of worship as a corporate activity at that time [12]. The original portico is the lowest and intermediate space. The crypt is a rectangular space higher than the portico and defined by a row of piers that allows spatial continuity with the south square. The tower's four separate spaces are bonded by a continuous spiral staircase that passes along the walls. The additions of the church hall and new tower have introduced some modifications (fig. 4b). The hall covers the entire portico and crypt area. It has two levels. The first floor contains a cluster of small rooms linked by a corridor, over the hall on the ground floor. The entrance area, with a staircase and the church's side entrance, has been added into the addition's space. The new tower has a ground floor and eight upper levels. The ground, first and second levels are not connected and have independent entrances. The upper levels consist of a vertical sequence of repetitive spaces connected by a staircase.

\subsection{Movement}

The original approach leads directly to the church's entrance, thus the goal of the approach is clear. The entrance is emphasized by a stone frame and its position. The original entrances to the tower and crypt are only possible through the portico, a permeable membrane. Originally, there were two main paths of movement (fig. 4a). The first connects the church entrance doorway and the centre of the shrine. The second is defined by the church's eastern side entrance and the entrance to the tower. They terminate in the chancel and the tower space and mark these as functionally and symbolically important spaces.

a

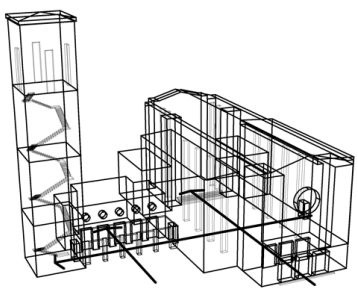

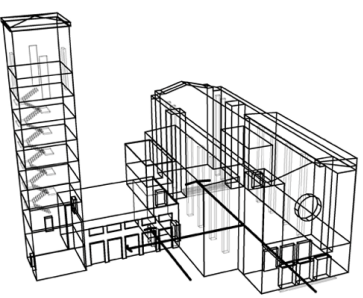

Figure 4: $\quad$ Space and form and movement: a) the original project, b) the new additions.

Today, the main approach is not clear due to the fence and a driveway that has made car parking possible on the south square location. The hall's entrance is simple, alongside the church wall. The new tower has three entrances on three different levels: on the ground floor, on the first floor and on the roof of the hall. The second main line of movement ends up in the church hall, thus denoting it as functionally important space (fig. 4b). A complex set of paths exist within the hall's addition today. The new tower path is not continuous. 


\subsection{Technology}

The basic load-bearing structure of the church, crypt and tower in the original design consists of massive parallel walls and ceilings. Today, the hall's and tower's load-bearing structures rest on significantly narrower walls. The hall's flat roof can be walked on. The material proposed in the original project was local stone with concrete reinforcements. The hall's façade is rendered and covered with a different kind of stone. The tower's concrete surface is merely painted.

\subsection{Perceptual reading}

Equilibrium and unity, as well as visual dominance are achieved by the tower's vertical and the horizontality of the large church form. The church's main entrance is emphasized by its central position and depth. The texture of the church's façade is in contrast to the surrounding urban texture. The side walls and the ceiling texture of the church emphasize the view towards the chancel (fig. 5a). All the church windows are higher than eye level, thus the church space is perceived higher than it is. The main inside views are directed to the church's altar. These views are also possible through the closed glazed church doors at all times. The form of the hall has changed the perception of the church-tower connection, because the original connecting passage is not there. There is a contrast in the originally designed windows (fig $5 \mathrm{~b}$ ) and the simplified, ordinary, rectangular shaped, larger windows of the additions (fig 5c). The large glassbrick windows of the hall's ground floor do not imitate the portico's passage successfully.
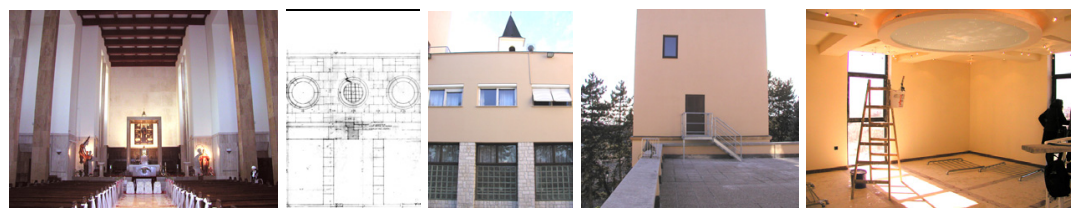

Figure 5: Textures and openings: a) the view towards the chancel, b) the original design of the crypt openings, c) the hall openings today, d) the tower entrance, e) the top-level interior.
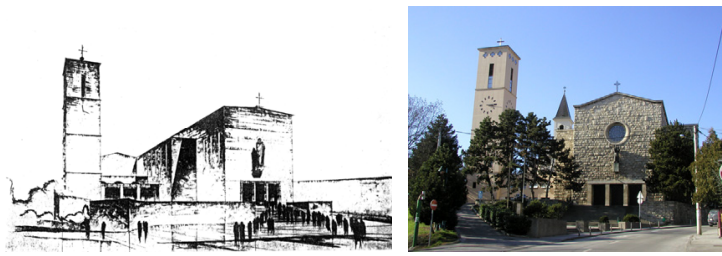

Figure 6: Perceptual and conceptual reading of the complex: a) the project, b) the built complex. 
The three existing entrances of the new tower can easily confuse the user/observer, and are not clearly designated (fig 5d). The additions' façade textures and their quality do not match the artefactual value of the work of highly skilled stone masons, and the interior textures are in disharmony with the additions' exterior (fig 5e). The views from the new top level of the tower reach the cathedral and enhance the possibilities for the tower's use.

\subsection{Conceptual reading}

A bell tower usually symbolizes a church in Croatian church architecture. It is a main symbol of the new complex. The second bell tower of the Holy Spirit chapel has not been removed as originally planned. Signs of religious tradition can be found in the bell tower's position and detachment, its highest openings in the shape of a cross, its clocks, the additive spatial organization of the composition, as well as in material such as wooden grid ceilings and stone walls. The purpose of the original composition elements is unambiguously defined by their form. Elements such as the new tower crosses and the clock details are enlarged, glazed and illuminated. The purpose of the added church hall is not clearly read.

\section{Discussion}

\subsection{About the method}

The analysis of architecture is not simple, because it is a highly complex system. An advantage of analysis is in a comprehensive approach where all aspects of the church and the additions are covered. However, some less than perfect aspects of the method have been indicated. The results of the analysis usually overlap due to the attributes' interaction. The perceptual and conceptual reading of a building is a subjective approach.

Nevertheless the analytic attributes contain unavoidable elements and approaches defined by international charters and guidelines. The Burra Charter stands out in its comprehensive definition of heritage. It defined cultural significance to be embodied in the place itself, its fabric, setting, use, associations, meanings, records, related places and related objects [4]. The main focuses of the international charters in cases of later additions are on the perceptual readings and space and form attributes of the analysis. Readings such as "compatible" and "harmonious integration", "sympathetic appearance to traditional setting", "feeling" [1, 2, 5-7, 13], represent users'/observers" perceptions of the building and its additions. "Shapes", "proportions, forms, sizes, scale" and "original traditional patterns of layout" $[1,5,13,14]$ are characteristics of the space and form attribute. The main focuses are followed by questions of the programme, context, technology and conceptual reading attributes. The programme is present as "use", "purpose" and "function" [3, 5, 6, 13]. A "site", "location" and "setting" $[5,6,12,13]$ are context attributes. 
"Materials" and "substance" $[2,5,13]$, "structural damage" and "material decay" [7], "crafts and techniques" [8, 13] as well as "artefactual value" [5] are analysed through the technology attribute of an architectural work. The special evaluation of "the spirit of the original" $[5,13]$ "the true value", "identity" [6] and "meaning" [1] is also present, thus the aspect of conceptual reading of the building is considered. On the other hand, the international charters and declarations rarely take the concept and the movement aspect of architecture into consideration. The concept attribute is present as "design" and "integrity" [5, 6, 13]. Movement needs more attention as a device that allows as an experience of a three-dimensional space through time. It has to be taken for an important aspect of architecture and therefore its preservation.

\subsection{The quality of the later additions}

The results of the analysis have shown that the continuous care and maintenance by the Franciscans resulted in the complex's redevelopment. The additions were made based on the original documentation and follow the position and to some extent the forms of the original composition. A greater number of autonomous space units for diverse activities have been achieved and the units have been also connected to the monastery. The use of new material has made the building process easier, faster and enlarged the usable interior area. A proper attempt [4] to retain the original visual setting has been made in dividing the hall's façade into five fields and using a tower as a symbol of the specific purpose and as a unifying element of the composition.

There are also several unfavourable aspects of the additions shown by the results. The absence of the participation of people who have professional responsibilities for the place, has led to the misinterpretation of the original design and to the absence of comprehensive plans. All the additions have been executed without the necessary observation of the whole composition and possible future developments. The value of the additions is further decreased by the existing car park in front of them. The additions' concept is based on the adjacency of autonomous elements without the necessary respect for the original patterns of movement that is clearly emphasized by the Appleton Charter [5]. The insufficient organization and use of the added spaces and their low quality are in disharmony with the church's design. There is also no consistency in the interior design of the additions and their exterior treatment. Poor quality of construction is present even though new material is used. The enlarged details such as the windows, tower clocks and glazed cross openings distort and obscure the cultural significance of the place and detract from its interpretation and appreciation, so the additions are not acceptable, according to the criteria of the Burra Charter [4]. Nor is the appropriate visual setting retained. The new tower has become the primary focus of the site instead of the unambiguous expressiveness of the original design of the church complex. Confusion is also created by the presence of the second bell tower of the Holy Spirit chapel, the same symbol. 


\subsection{Authenticity issue}

The results have shown that the additions do not correspond to Denzler's original idea and intentions. A low level of truthfulness of the internal unity of the creative process and the physical realization of the work brings into question the composition's authenticity. The Declaration of San Antonio elaborates the issue defining authenticity indicators. They are considered to be a reflection of the true value, integrity, context, identity and use and function [6]. The true value of the composition's creation and its significant history cannot be discussed in the case of the later additions. The only built element to evaluate, as such, is the church, but it is just part of the composition in this case. The major problem for the later additions lies in the concept of integrity. It is believed that the aspects of integrity are location, design, setting, materials, workmanship, feeling and association [16]. The results have shown that in all of these aspects the later additions do not reach a satisfactory level, thus do not represent the composition as a unique product (fig. 8). Unfortunately the activities of the re-creation of the details of the original forms are achieved with conjecture, and the additions impair the aesthetic integrity, and that is not agreeable [5]. It is true that the diversity of cultures and heritage in our world is an irreplaceable source of spiritual and intellectual richness for all humankind, as stated in the Nara Document on Authenticity [13]. The original design of the composition has elements of Croatian heritage architecture and yet again only the perceptual and conceptual readings of the new tower repeat the cultural message to some extent, which seems to be aggressive and unfounded. Authenticity has to be also taken into account in a process of usability and value enhancement. The process has to reflect favourably upon its urban surroundings and even beyond this immediate area to more distant ones [12].

The study has shown that the distraction from the composition's nature has appeared in utilizing the hall and tower spaces in order to perform their new assigned functions. The notion of the portico does not exist and that of the new tower is disrespected by excessive unused spaces, movement paths and the illuminated enlarged openings and clocks at night. The tower looks like a lighthouse and it is in discord with the charter's recommendations $[4,12]$.

\section{Conclusion}

This study has shown that continuous care and maintenance have resulted in the redevelopment of this place. But even when the original documentation and new
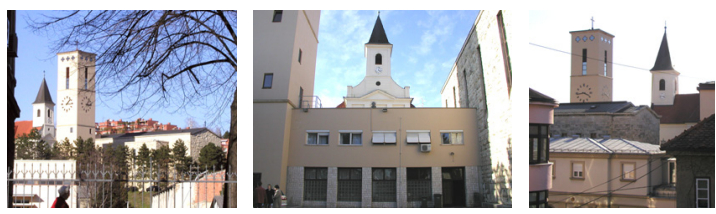

Figure 7: Disintegration. 
materials have been used to satisfy the current needs and attempts have been made to retain the original visual setting, without professional participation and comprehensive study all the additions result in misinterpretation of the original design and the absence of quality solutions, as presented in the case of the Saint Anthony of Padua complex. All the additions have been executed without the necessary observation of the whole composition. The insufficient organization and use of the added spaces and their low quality are in disharmony with the church's design, the true heritage value. There is also no consistency in the interior design of the additions and their exterior treatment. The distortion of perception and appreciation is therefore emphasized.

Special care has to be taken over the authenticity of the place and its new additions, considering integrity, identity, use and function as its major indicators. The cultural significance of the place has to be retained at all times.

The new additions to the church of Saint Anthony of Padua have pointed out the haziness of the terms of reference in contemporary architectural conservation practice. The method used in this study proved to be a comprehensive and useful tool. It is possible to create appropriate later additions to built heritage, but elements, such as programme, context, concept, form and space, movement, technology as well as perceptual and conceptual readings, have to be carefully evaluated before making decisions.

\section{References}

[1] Act on the Protection and Preservation of Cultural Goods. Croatian Republic's Ministry of Culture Web Site. www.min-kulture.hr

[2] International Charter for the Conservation and restoration of monuments and sites (The Venice Charter - 1964); Charters Adopted by the General Assembly of ICOMOS, ICOMOS Online. www.international.icomos.org/ charters/venice_e.htm

[3] Charter for the Conservation of Places of Cultural Heritage Value (ICOMOS New Zealand, 1992); Charters Adopted by ICOMOS National Committées; ICOMOS Online. www.icomos.org/docs/nz_92charter.html

[4] The Australia ICOMOS Charter for the Conservation of Places of Cultural Significance (The Burra Charter - Australia ICOMOS); Charters Adopted by ICOMOS National Committées; ICOMOS Online. www.icomos.org/ australia/burra.html

[5] Appleton Charter for the Protection and Enhancement of the Built Environment (ICOMOS Canada, 1983); Charters Adopted by ICOMOS National Committées; ICOMOS Online. www.international.icomos.org/ charters/appleton.pdf

[6] Declaration of San Antonio at the InterAmerican Symposium on Authenticity in the Conservation and Management of the Cultural Heritage; Resolutions and Declarations of ICOMOS Symposia; ICOMOS Online. www.icomos.org/docs/san_antonio.html

[7] ICOMOS Charter - Principles for the Analysis, Conservation and Structural Restoration of Architectural Heritage (2003); Charters Adopted 
568 Structural Studies, Repairs and Maintenance of Heritage Architecture XI

by the General Assembly of ICOMOS, ICOMOS Online. www.international.icomos.org/charters/structures_e.htm

[8] Declaration of Amsterdam (Congress on the European Architectural Heritage, 21-25 October 1975); Other International Standards; ICOMOS Online. www.icomos.org/docs/amsterdam.html

[9] Jaksic, N., Arhitektonski opus Jurja Denzlera tridesetih godina dvadesetog stoljeca. Doctoral thesis. Arhitektonski fakultet Sveucilista u Zagrebu: Zagreb, pp. 40-62, 2007.

[10] Jaksic, N., The Chapel on Sljeme, Zagreb: Heritage Messages and Their Expression in Architectural Design Forms, Proc. Of the $5^{\text {th }}$ International Conference of the Centre for Study of Architecture in The Arab Region, eds. S. Elwazani, S. Malhis, J. Al-Qawasmi, CSAAR: Amman, pp. 447-462, 2008.

[11] Kordic, A. Mjesto za molitvu. Veritas Online. www.ver.hr/arhiv/arhiv/ ver2001/Ver6-01/predstav.htm

[12] Sokol Gojnik, Z. Duh modern i nova liturgijska strujanja na primjeru crkve Gospe od Zdravlja u Splitu. Croatica Christiana Periodica, 59, pp. 143 $162,2007$.

[13] The Nara Document on Authenticity (Nara Conference on Authenticity in Relation to the World Heritage Convention, held at Nara, Japan, from 1-6 November 1994); Resolutions and Declarations of ICOMOS Symposia; ICOMOS Online. www.international.icomos.org/charters/nara_e.htm

[14] European Charter of the Architectural Heritage (Council of Europe, October 1975); Other International Standards; ICOMOS Online. www.icomos.org/docs/euroch_e.html

[15] Normas de Quito, 1967 (Informe final de la reunión sobre la conservación y utilización de monumentos y lugares de interés histórico y artístico); Other International Standards; ICOMOS Online. www.international.icomos.org/ charters/quito.htm

[16] Jokilehto, J., A History of Architectural Conservation, Elsevier, Oxford, pp. 296-299, 1999. 